\title{
SEISMICKÉ JEVY REGISTROVANÉ STANICÍ VRAC V ROCE 2017
}

\author{
Seismic events recorded by station VRAC during year 2017
}

\author{
Josef Havír $\square$ \\ Ústav fyziky Země, PřF MU, Tvrdého 12, 60200 Brno
}

Key words: seismic monitoring, induced seismic events, natural seismicity, detectability, station VRAC

\begin{abstract}
Broadband seismic station VRAC, operated by Institute of Physics of the Earth (Masaryk University) and situated westwards of village Vranov u Brna, is equipped with seismometer STS-2 high gain and by digitizer Quanterra Q330. This instrumentation allows recording of broad band of frequencies from tenths of $\mathrm{Hz}$ to hundreds of seconds. It is important for usage of the VRAC station, which is part of several seismic networks, including Czech regional seismic network and global International Monitoring System of the CTBTO. In frame of these networks, station VRAC has to record of seismic signal of both local and teleseismic events. During year 2017, station VRAC recorded 6855 seismic events (10 699 picked seismic phases). More than 70\% of recorded events were represented by local events with epicentral distance less than $360 \mathrm{~km}$. Induced events (mining tremors) and quarry blasts dominated among these local events. In addition, 197 natural tectonic events were recorded (89 on the territory of the Czech Republic). In the region of the Bohemian massif, most important natural seismicity was observed in the area of west Bohemia, where seismic swarm occured in July 2017. Exceptional tectonic event (10.12. 2017, ML =3.5) was recorded from the NE part of the Bohemian Massif (near Hlučín). About 25\% of events registered by station VRAC were represented by teleseismic events with epicentral distance exceeding $2000 \mathrm{~km}$, including Korean nuclear test from 3. 9. 2017. Records of relatively small teleseismic events show significant effect of the PKP caustic zone in respect of detectability of station VRAC.
\end{abstract}

\section{Úvod}

Širokopásmová seismická stanice VRAC, provozovaná Ústavem fyziky Země (ÚFZ) Masarykovy univerzity a situovaná západně od obce Vranov u Brna, je vybavena seismometrem STS-2 high gain a digitizérem Quanterra Q330. Toto př́strojové vybavení umožňuje při vzorkovací frekvenci $100 \mathrm{~Hz} v$ dobré kvalitě zaznamenávat seismický signál ve velkém rozsahu frekvencí a sledovat tak celou škálu seismických jevů od velmi blízkých otřesů až po vzdálená (teleseismická) zemětřesení.

Zmíněný širokopásmový charakter stanice je důležitý z hlediska jejího využití. Stanice VRAC je od roku 2002 certifikovanou stanicí globální sítě Mezinárodního monitorovacího systému CTBTO (Comprehensive Nuclear-Test-Ban Treaty Organization) jako pomocná stanice AS26 (Havír et al. 2003). Hlavním smyslem této globální sítě je globální seismické monitorování za účelem verifikace dodržování Smlouvy o úplném zákazu jaderných zkoušek. Tato role vyžaduje, aby stanice byla schopna zaznamenávat jak regionální, tak i vzdálené (teleseismické) jevy, včetně sekundárních fází a povrchových vln. Stanice tedy musí být schopna zaznamenat seismický signál ve frekvencích od jednotek hertz až po první stovky sekund. Současně je stanice VRAC součástíl lokálních a regionálních seismických sítí, včetně např. České regionální seismické sítě (Zedník, Pazdírková 2014). Pro sledování blízkých jevů je pak nutné, aby záznam seismického signálu sahal do ještě vyšších frekvencí, tedy do hodnot až prvních desítek hertz.

Seismická stanice VRAC je tedy schopná zaznamenávat jak blízké, tak i vzdálené seismické jevy. Smyslem

$\rightrightarrows$ havir@ipe.muni.cz

DOI: https://doi.org/10.5817/GVMS2018-1-2-113 tohoto článku je stručně ukázat, jaké množství seismických jevů tato stanice registruje během jednoho roku, a to na př́kladu jevů zaznamenaných během roku 2017.

V roce 2017 zaregistrovala stanice VRAC celkem 6855 seismických jevů (tab. 1). Vzhledem k tomu, že seismický záznam je komplexní a často je na něm možné odečíst časy příchodu více než jedné seismické fáze, je celkový počet seismických fází odečtených na stanici VRAC během zmíněného roku ještě vyšší (celkem 10699 odečtených časů prííchodů seismických fází).

Tab. 1: Počty seismických jevů registrovaných stanicí VRAC v roce 2017 podle epicentrální vzdálenosti.

Tab. 1: Numbers of seismic events registered by station VRAC during the year 2017 according to epicentral distance.

\begin{tabular}{|l|c|}
\hline & počet jevů \\
\hline epicentrální vzdálenost do $360 \mathrm{~km}$ & 4888 \\
\hline epicentrální vzdálenost od 360 do $2000 \mathrm{~km}$ & 272 \\
\hline epicentrální vzdálenost nad $2000 \mathrm{~km}$ & 1694 \\
\hline neidentifikované & 1 \\
\hline CELKEM & $\mathbf{6 8 5 5}$ \\
\hline
\end{tabular}

\section{Blízké seismické jevy}

\section{(epicentrální vzdálenost do $360 \mathrm{~km}$ )}

Více než $70 \%$ všech zaznamenaných jevů je reprezentováno blízkými seismickými jevy (epicentrální vzdálenost do $360 \mathrm{~km}$ ), jejichž epicentra byla situována nejen na území České republiky, ale také v přilehlých částech Rakouska, Madarska, Slovenska, Polska a Německa (obr. 1). Mezi těmito blízkými jevy dominovaly záznamy indukovaných jevů (převážně důlních otřesů - celkem 2717 jevů) a explozí v lomech (celkem 1974 jevů). Pouze přibližně $4 \%$ zaznamenaných blízkých jevů bylo v roce 2017 reprezentováno přirozenými tektonickými otřesy (tab. 2). 


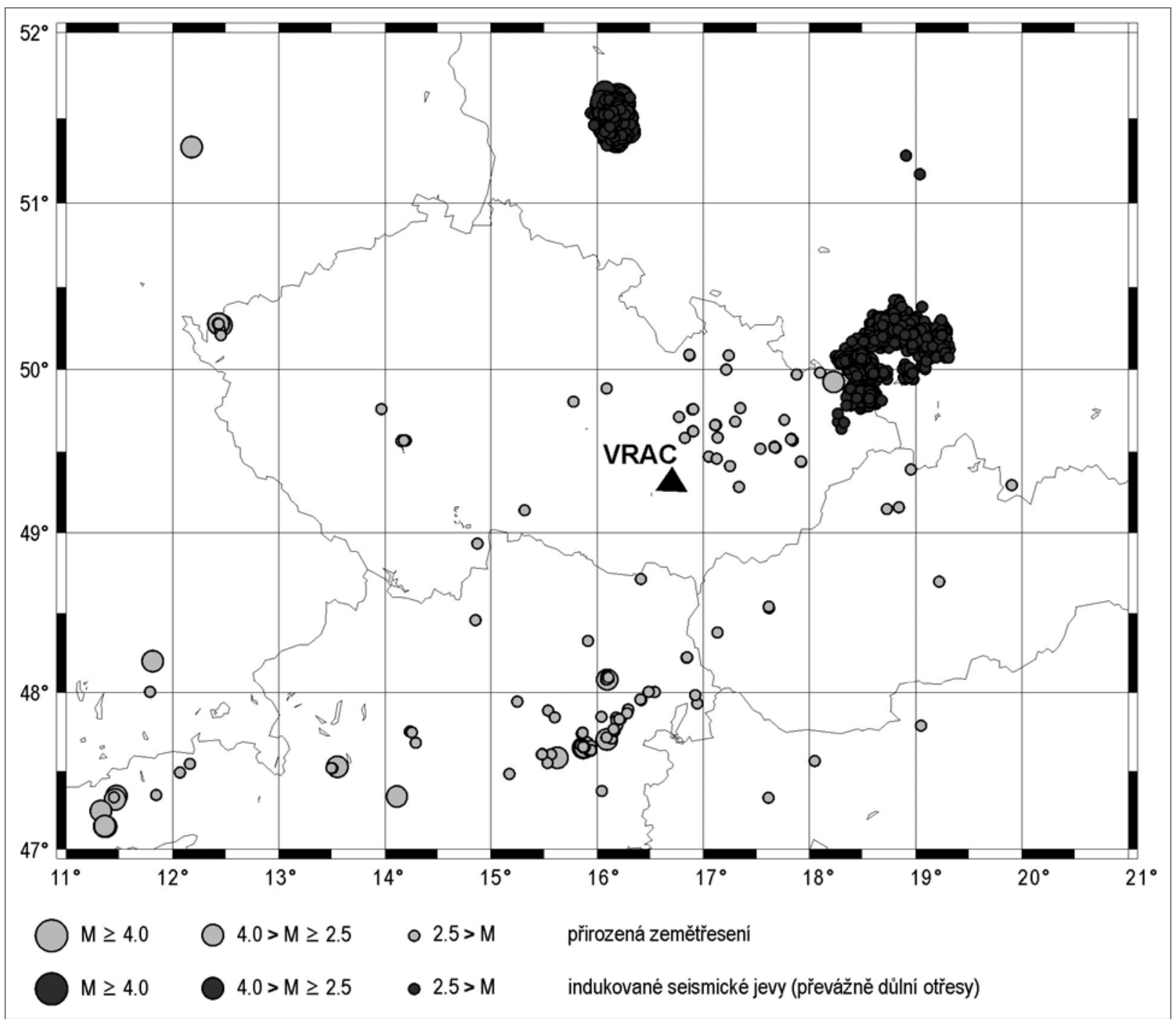

Obr. 1: Schematická mapa epicenter seismických jevů (s výjimkou explozí v lomech) registrovaných stanicí VRAC v roce 2017 (region České republiky a blízkého okolí).

Fig. 1: Schematic map of epicentres of seismic events (except quarry blasts) recorded by station VRAC during the year 2017 (area of the Czech Republic and surrounding regions): light grey - natural tectonic events; dark grey - induced events (mining tremors).

Přímo na území České republiky zaznamenala stanice VRAC během roku 2017 celkem 89 přirozených tektonických otřesů. Většinou šlo o slabá mikro-zemětřesení

Tab. 2: Počty blízkých seismických jevů (epicentrální vzdálenost do $360 \mathrm{~km}$ ) registrovaných stanicí VRAC v roce 2017 (na území České republiky a mimo toto území) podle jejich původu.

Tab. 2: Numbers of local seismic events (epicentral distance less than $360 \mathrm{~km}$ ) registered by station VRAC during the year 2017 (on the territory of the Czech Republic and outside of this territory) according their origin.

\begin{tabular}{|l|c|}
\hline epicentrální vzdálenost do $\mathbf{3 6 0} \mathbf{~ k m}$ & počet jevů \\
\hline na území ČR & 2284 \\
\hline indukované jevy & 830 \\
\hline tektonické otřesy & 89 \\
\hline exploze & 1365 \\
\hline mimo území ČR & 2604 \\
\hline indukované jevy & 1887 \\
\hline tektonické otř̌esy & 108 \\
\hline exploze & 609 \\
\hline CELKEM & $\mathbf{4 8 8 8}$ \\
\hline
\end{tabular}

s hodnotou lokálního magnituda ML menší než 1 . Pouze $\mathrm{v}$ př́padě osmnácti tektonických otřesů s epicentrem na území České republiky dosáhlo jejich lokální magnitudo ML hodnoty 2 nebo více. Šlo především o otřesy náležející seismickému roji, který se projevil v červenci 2017 v západních Čechách, a to v epicentrální oblasti ssv. od obce Luby. Lokální magnitudo ML nejsilnějšího západočeského otřesu ze zmíněného seismického roje (11. 7. 2017 11:58 UTC), vypočtené na základě dat stanic ÚFZ, dosáhlo hodnoty 3,3.

Výjimečným tektonickým otřesem bylo zemětřesení ze dne 10. 12. 2017, jehož epicentrum bylo situováno ssv. od Hlučína. Lokální magnitudo ML tohoto jevu, vypočtené v ÚFZ, dosáhlo hodnoty 3,5 a jednalo se tak o nejsilnější tektonický otřes na území České republiky v roce 2017. Projevy přirozené seismické aktivity jsou sice z prostoru sv. části Českého masivu dobře známy (např Špaček et al. 2006, 2015), v posledních desetiletích se ovšem jednalo zpravidla o mikro-zemětřesení s magnitudem o hodnotě 


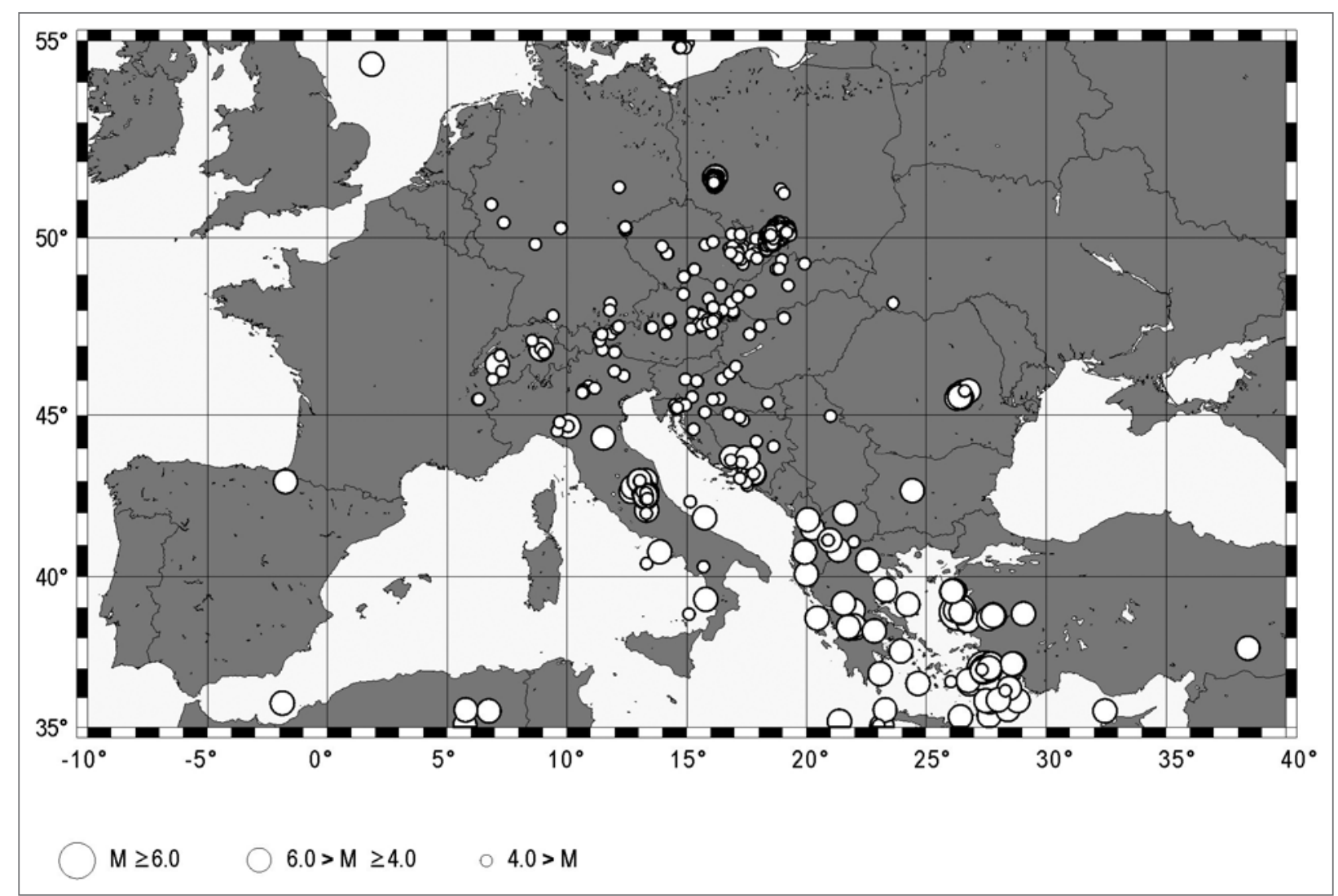

Obr. 2: Schematická mapa epicenter seismických jevů (s výjimkou explozí v lomech) registrovaných stanicí VRAC v roce 2017 (region Evropy).

Fig. 2: Schematic map of epicentres of seismic events (except quarry blasts) recorded by station VRAC during the year 2017 (Europe area).

menší než 2, jen výjimečně byly pozorovány silnější jevy $s$ magnitudem presahujícím hodnotu 2.

Mimo území České republiky zaznamenala stanice VRAC dalších 108 tektonických otřesů s epicentry ve vzdálenosti do $360 \mathrm{~km}$ od stanice, převážná většina z nich se vyskytla na území Rakouska. Významné projevy seismické aktivity byly pozorovány především v zóně Mur-Mürz-Leitha. Epicentrum nejsilnějšího otřesu zaznamenaného $\mathrm{v}$ roce $2017 \mathrm{z}$ tohoto prostoru bylo situováno u obce Neunkirchen (10. 11. 2017, dle ÚFZ Brno $M L=3,3$, dle bulletinu rakouské seismické služby $\mathrm{ML}=3,7)$. Zóna Mur-Mürz-Leitha patří k seismicky nejaktivnějším strukturám v prostoru Východních Alp (Lenhardt et al. 2007) a jsou s ní spojena také středně silná zemětřesení s hodnotou lokálního magnituda ML vyšší než 4 . Naposledy se v diskutované zóně vyskytly takto silné otřesy v roce 2013 v blízkosti obce Ebreichsdorf (Apoloner et al. 2015).

Významný tektonický otřes byl v roce 2017 zaregistrován také z prostoru zsz. od Vídně, v blízkosti obce Alland (8. 11. 2017, dle ÚFZ Brno ML = 3,3, dle bulletinu rakouské seismické služby $\mathrm{ML}=3,1)$. Ve stejné oblasti se v roce 2016 vyskytlo zemětřesení, jehož lokální magnitudo ML dosáhlo hodnoty 4,2, a které bylo široce makroseismicky pozorováno v j. regionech České republiky. Severně od obce Alland je také kladeno epicentrum nejsilnějšího známého historického zemětřesení z území Rakouska, a to otřesu z roku 1590 (Hammerl, Lenhardt 2013).
Indukovanými seismickými jevy jsou myšleny takové otřesy, které vznikají sice samovolně, ale jejich vznik je podmíněn lidskou činností ovlivňující stav napětí v zemské kůře. Typicky jde například o důlní otřesy související s napětovými změnami při těžbě nerostných surovin. Všechny indukované seismické jevy zaznamenané stanicí VRAC v roce 2017 byly reprezentovány právě důlními otřesy. Epicentra těchto otřesů se nacházela zejména v prostoru Hornoslezské pánve (a to jak v české, tak i v polské části této pánve) a v blízkosti Lubinu v jz. Polsku (obr. 1). Ojediněle byly zaznamenány také důlní otřesy z regionu Belchatowa (Polsko). Lokální magnitudo ML nejsilnějšího z diskutovaných důlních otřesů (26. 12 . 2017, Lubin) dosáhlo hodnoty 4,4 (dle ÚFZ). Vzhledem $\mathrm{k}$ relativně nízké úrovni přirozené seismické aktivity ve střední Evropě tak představuje indukovaná seismicita nejvýznamnější zdroj seismicity v epicentrální vzdálenosti $360 \mathrm{~km}$ od stanice VRAC, a to jak co do četnosti, tak i co do velikosti otřesů.

Záznamy explozí v lomech zpravidla nejsou, kromě jejich identifikace, detailněji zkoumány. Nicméně lze alespoň konstatovat, že jde o jevy, jejichž hodnota lokálního magnituda ML často přesahuje hodnotu 1, ojediněle i hodnotu 2. Například exploze v lomu Bílina v západních Čechách ze dne 17. 2. 2017 se projevila jako seismický jev s hodnotou lokálního magnituda ML 2,1 (dle ÚFZ). Vzhledem k tomu, že Český masiv je seismicky velmi klidným regionem, představují záznamy explozí v lomech 


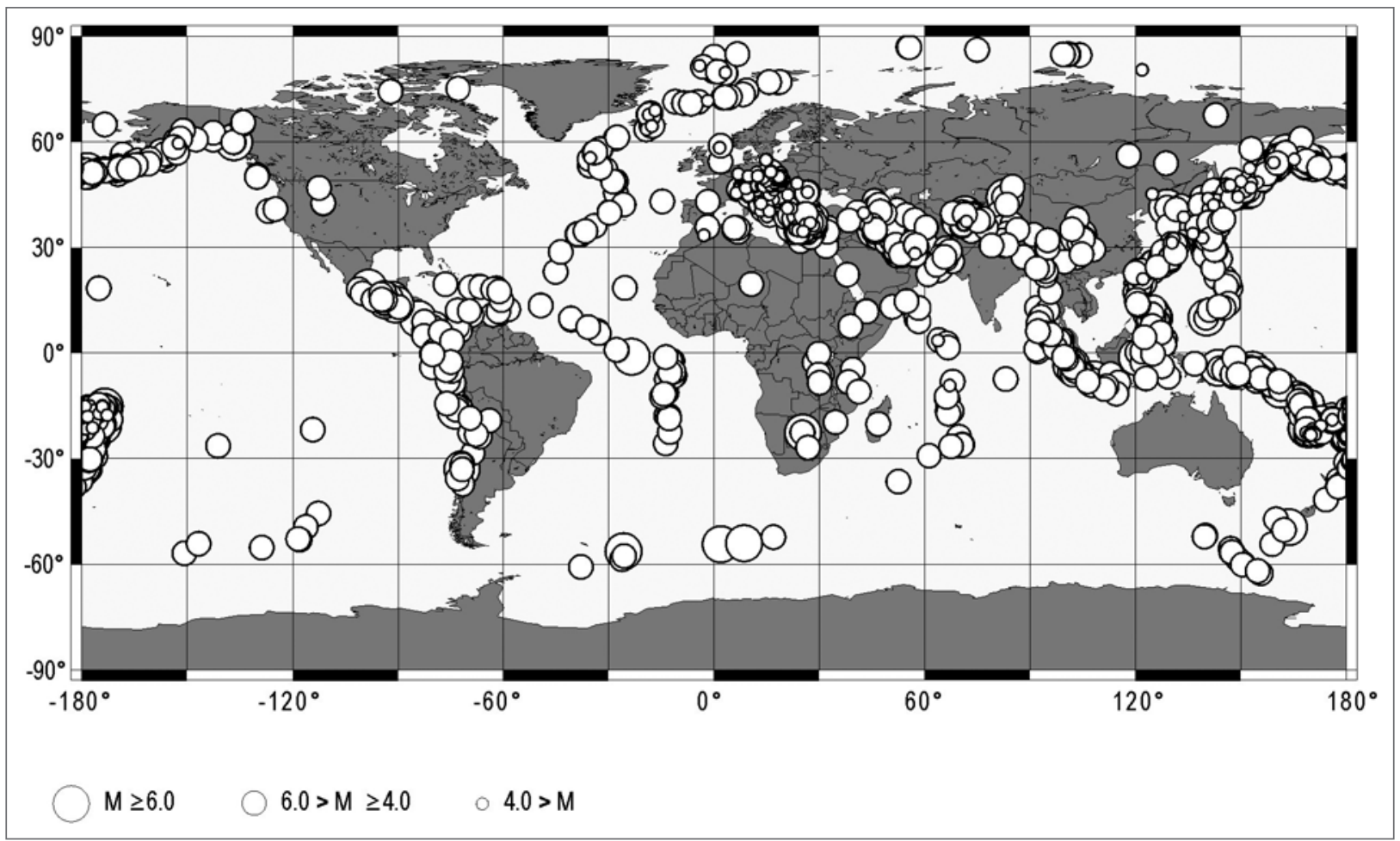

Obr. 3: Schematická mapa epicenter seismických jevů registrovaných stanicí VRAC v roce 2017 (celý svět).

Fig. 3: Schematic map of epicentres of seismic events recorded by station VRAC during the year 2017 (global scale - whole world).

seismické jevy, které jsou amplitudově srovnatelné s většinou registrací přirozených tektonických otřesů. I když je v řadě př́padů dobře patrný rozdíl v charakteristice tvaru seismického signálu explozí a přirozených zemětřesení, je nezbytné $\mathrm{v}$ rámci monitorování přirozené seismické aktivity věnovat pozornost také explozím, protože je nutné zajistit dostatečně spolehlivou identifikaci jak př́irozených otřesů, tak i explozí, aby nedocházelo k záměně těchto jevů.

\section{Regionální seismické jevy a teleseismické jevy}

Stanice VRAC zaregistrovala v roce 2017 celkem 272 regionálních zemětřesení s epicentry ve vzdálenosti 360 až $2000 \mathrm{~km}$ od stanice a 1694 vzdálených (teleseismických) jevů s epicentrální vzdáleností nad $2000 \mathrm{~km}$ (tab. 1, obr. 2 a 3).

Menší počet regionálních a vzdálených jevů oproti záznamům jevů blízkých (s epicentry ve vzdálenosti do $360 \mathrm{~km}$ ) je dán klesající detekční schopností stanice s rostoucí epicentrální vzdáleností, která se projevuje především v regionálním měřítku (obr. 4). Zatímco ve velmi malých vzdálenostech (méně než $100 \mathrm{~km}$ ) je možné zaznamenat i otřesy se zápornými hodnotami lokálního magnituda, ve vzdálenostech nad $400 \mathrm{~km}$ je již obtížné zaregistrovat slabší otřes než jev s magnitudem o hodnotě 2 , a ve vzdálenostech nad $1000 \mathrm{~km}$ pak již byla registrace dosahována pouze u jevů, jejichž magnitudo zřetelně přesáhlo hodnotu 3 . $V$ př́padě teleseismických jevů se pak v epicentrálních vzdálenostech do $90^{\circ}$ (přibližně $10000 \mathrm{~km}$ ) projevuje závislost detekční schopnosti seismických stanic na epicentrální vzdálenosti již mnohem méně výrazně. Zřetelně však lze pozorovat výrazný pokles četnosti zaregistrovaných jevů s epicentry ve vzdálenos- tech $104^{\circ}$ až $140^{\circ}$ a naopak zřetelný nárůst počtu středně silných otřesů s epicentry ve vzdálenostech cca $144^{\circ}$ až $145^{\circ}$. První efekt souvisí s existencí zóny seismického stínu způsobené sníženými rychlostmi seismických vln ve vnějším jádře. Do této zóny nesměřují žádné paprsky př́imých vln a jsou zde tedy registrovány pouze odražené seismické fáze nesoucí menší energii, což znemožňuje spolehlivé zaznamenání signálu slabších otřesů. Druhý ze zmíněných efektů pak souvisí s existencí tzv. zóny kaustiky PKP vln, kdy do jednoho místa přichází ve stejnou dobu seismický signál po více různých drahách a interferencí tohoto signálu pak dochází k zesílení amplitud seismické vlny.

Přestože počet zaznamenaných regionálních a teleseismických jevů je menší než počet blízkých otřesů s epicentry ve vzdálenostech do $360 \mathrm{~km}$, není tento počet rozhodně zanedbatelný. Záznamy vzdálených (teleseismických) jevů představují přibližně čtvrtinu všech registrací stanice VRAC.

Epicentra regionálních otřesů zaznamenaných v roce 2017 stanicí VRAC se nacházela především v j. části Evropy a v prostoru Středozemního moře. Nejvýraznější seismická aktivita se projevovala v regionu Řecka, Egejského moře, Dodekanéských ostrovů a západního Turecka. Momentové magnitudo Mw dvou otřesů s epicentry při západním pobřeží Turecka přesáhlo podle údajů EMSC (European-Mediterranean Seismological Centre) dokonce hodnotu 6 (20. 7. 2017, $\mathrm{Mw}=6,6$; 12. 6. 2017, $\mathrm{Mw}=6,3)$. Významné projevy seismické aktivity byly pozorovány také $\mathrm{v}$ regionu střední Itálie, magnitudo mb určené z objemových vln nesilnějšího otřesu z tohoto prostoru (18. 1. 2017) dosáhlo dle EMSC hodnoty 5,7.

Mezi vzdálenými seismickými jevy zaznamenanými v roce 2017 stanicí VRAC dominovalo svou velikostí 


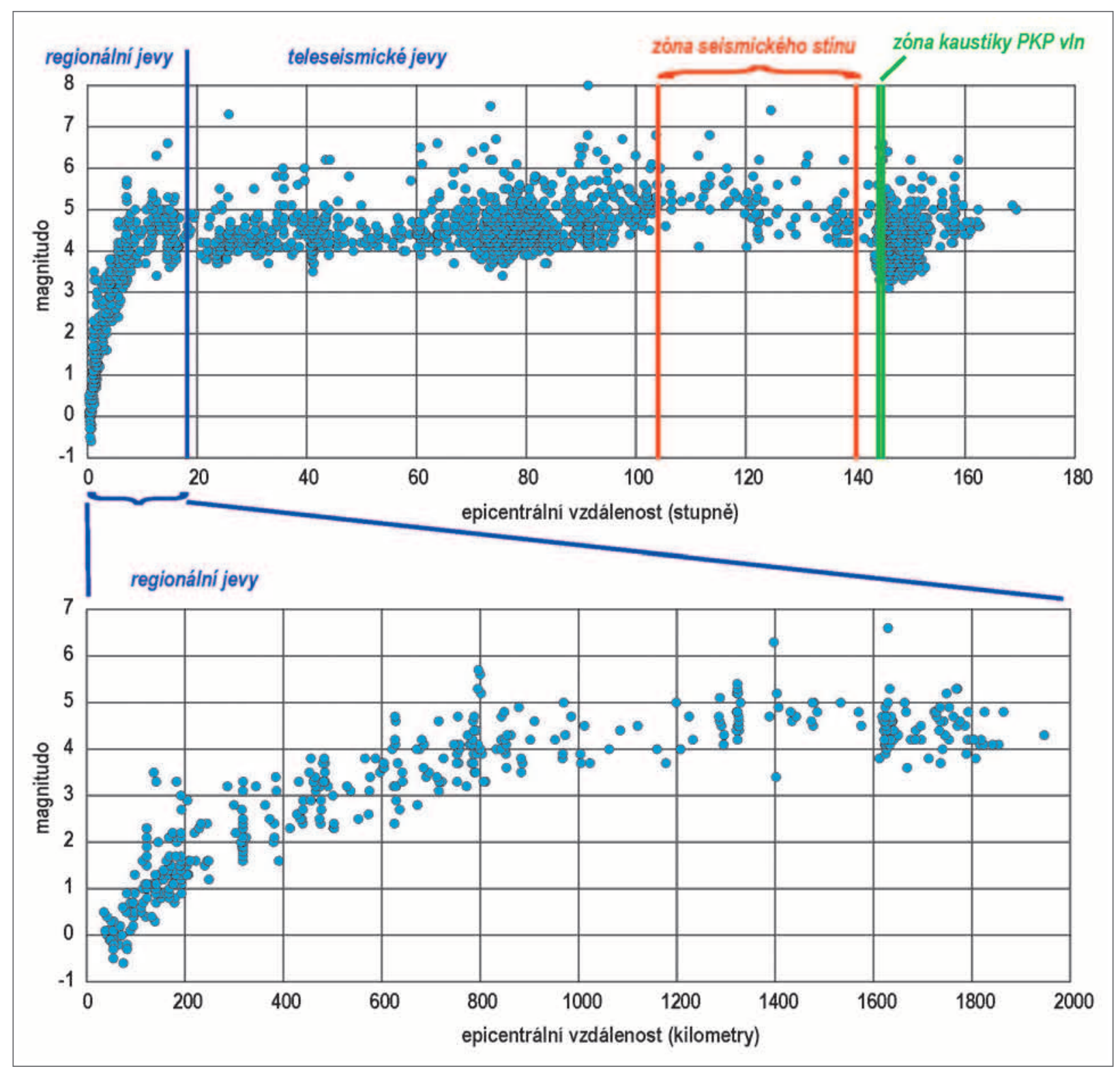

Obr. 4: Schematický graf ukazující magnitudo seismických jevů registrovaných stanicí VRAC v roce 2017 vůči jejich epicentrální vzdálenosti od stanice VRAC (nahoře - globální měřítko, vzdálenost ve stupních; dole - lokální a regionální jevy, vzdálenost v kilometrech).

Fig. 4: Graph of the magnitude of seismic events registered by station VRAC during the year 2017 plotted against their epicentral distance (at the top - global scale, distance in degrees; at the bottom - local and regional events, distance in kilometers).

ničivé zemětřesení s epicentrem při pobřeží státu Chiapas (Mexiko), jehož magnitudo dosáhlo podle seismologické služby NEIC (USA) hodnoty 8,1 . Kromě tohoto zemětřesení se v roce 2017 vyskytly ještě další tři silná zemětřesení s magnitudem vyšším než 7 (22. 1. 2017, Šalamounovy ostrovy, Ms = 7,4; 17. 7. 2017, Komandorské ostrovy, Ms = 7,5; 12. 11. 2017, pohraničí Íránu a Iráku, Ms = 7,3 - Ms je magnitudo počítané z povrchových vln, uvedené hodnoty jsou převzaty z bulletinu CTBTO). Takto silná zemětřesení jsou samozřejmě celosvětově spolehlivě registrována, a to i stanicemi nacházejícími se v zóně seismického stínu. Z hlediska detekčních možností jsou zajímavé naopak registrace slabých vzdálených seismických jevů. V tomto ohledu lze dobře ilustrovat vliv kaustiky PKP vln na prríkladu registrací zemětřesení s epicentrem v prostoru souostroví Fidži, kdy magnitudo mb počítané z objemo- vých vln nejslabších jevů z diskutovaného prostoru mělo v př́padě otřesů zaregistrovaných stanicí VRAC hodnotu pouze 3,3 (dle bulletinu CTBTO). Tak slabé jevy je obtížné zaznamenat i v regionálních vzdálenostech nad $1000 \mathrm{~km}$.

Naprostá většina teleseismických jevů je reprezentována přirozenými zemětřeseními. Výjimkou byla $\mathrm{v}$ roce 2017 jaderná exploze provedená dne 3. 9. 2017 na jaderné střelnici Punggye-ri v sv. části KLDR. Šlo o zatím nejsilnější severokorejskou jadernou explozi. Magnitudo mb počítané z objemových vln dosáhlo podle záznamů stanic ÚFZ hodnoty 6,4.

\section{Závěr}

Statistický přehled registrací stanice VRAC v roce 2017 ukazuje poměrně vysoké počty registrovaných seismických jevů. Stanice VRAC poskytuje každoročně 
řádově tisíce záznamů jak blízkých, tak i vzdálených otřesů. Její data tak představují významný příspěvek pro seismické monitorování ve všech měřítkách, od lokálního monitorování až po globální (celosvětové) měřítko.

\section{Poděkování}

Př́spěvek vznikl sinanční podporou projektu MŠMT, program č. LM2015079, CzechGeo/Epos. Autor děkuje oběma recenzentiom za jejich pripomínky.

\section{Literatura}

Apoloner, M. T., Tary, J. B., Bokelmann, G. (2015). Ebreichsdorf 2013 earthquake series: Relative location. - Austrian Journal of Earth Sciences, 108, 2, 199-208.

Hammerl, Ch., Lenhardt, W. A. (2013). Erdbeben in Niederösterreich von 1000 bis 2009 n. Chr. - Abhandlungen der Geologischen Bundesanstalt, 67, 3-297.

Havír. J., Švancara, J., Otruba, J. (2003). Úloha a využití nově certifikované seismologické stanice VRAC v rámci Mezinárodního monitorovacího systému CTBTO. - In: Sborník 12. regionální konference „Nové výsledky seismologických, geofyzikálních a geotechnických průzkumů“. Sborník vědeckých prací VŠB-TU Ostrava, řada stavební, 3, 2, 77-84.

Lenhardt, W. A., Švancara, J., Melichar, P., Pazdírková, J., Havíŕ, J., Sýkorová, Z. (2007). Seismic activity of the Alpine-Carpathian-Bohemian Massif region with regard to geological and potential field data. - Geologica Carpathica, 58, 4, $397-412$.

Špaček, P., Sýkorová, Z., Pazdírková, J., Švancara, J., Havíŕ, J. (2006). Present-day seismicity of the south-eastern Elbe Fault System (NE Bohemian Massif). - Studia geophysica et geodaetica, 50, 2, 233-258.

Špaček, P., Bábek, O., Štěpančíková, P., Švancara, J., Pazdírková, J., Sedláček, J. (2015). The Nysa-Morava Zone: an active tectonic domain with Late Cenozoic sedimentary grabens in the Western Carpathians' foreland (NE Bohemian Massif). - International Journal of Earth Sciences, 104, 963-990. https://doi.org/10.1007/s00531-014-1121-7

Zedník, J., Pazdírková, J. (2014). Seismic activity in the Czech Republic in 2012. - Studia geophysica et geodaetica, 58, $342-348$. https://doi.org/10.1007/s11200-013-1290-z. 